\title{
<ラスマルテンサイト組織の強度発現機構と劣化過程のモデル化と シミュレーションに関する場の理論的研究>
}

$<$ FTMP-based Modeling and Simulation for Intensity and Degradation in Lath Structures $>$

<飯田 真士 (神戸大院) >

< Masashi Iida, Graduate School of Engineering , Kobe University>
<長谷部 忠司 (神戸大) >

$<$ Tadashi Hasebe , Kobe University $>$

Key Words: <FTMP, lath martensite, lathpacket, imcompatibility tensor, creep >

\section{1. 諸言}

火力発電所等で使用されている高クロムフェライト耐熱 鋼は，優れた高温強度と熱的特性を持つ材料であるが, 高 温・長時間において, クリープ強度が低下するということが わかっている.この高クロムフェライト系耐熱鋼はラス, ラ スブロック, ラスパケット組織と階層的な構造をしている. そのため, それぞれの組織を分離しての評価は困難であり、 これらを統合した多重スケールでの評価法が求められてい る.

そこで本研究では場の理論に基づき, 多重スケールを考慮 したラスパケット組織のモデル化を目的とする. その予備解 析として, 転位密度, 分布を表現するのに不適合度テンソル $\eta$ を用い, 初期ひずみ分布を与えた解析を行うことで忘力場 のゆらぎを伴うラス組織を表現する. ラス組織の模擬を行い, エネルギ・方位差の観点からモデルの妥当性を評価する. そ の後, ラスパケット組織のモデル化を行い, 不均質な回復が 起こる際，上位・下位スケールのスケール間での相互作用を エネルギ・エネルギのゆらぎ・不適合度の観点から検討する.

\section{2. 構成式と相互作用場}

不適合度テンソルおよび相互作用場について, $\eta^{(\alpha)}$ は不適 合度テンソル $\eta$ の $\alpha$ ずり系への写像として,すべり方向お よびすべり線方向単位ベクトル $s, t$ を用いて

$$
\eta^{(\alpha)}=\left(s^{(\alpha)} \otimes t^{(\alpha)}\right): \eta
$$

となる. 不適合度テンソルは $\varepsilon^{p}$ の 2 階微分として

$$
\eta=\nabla \times \nabla \times \varepsilon^{p}
$$

で定義される 2 階のテンソル量である. 不適合度を通してス ケール間の相互作用が導入される.

また本研究では結晶塑性方程式において硬化比にひずみ 勾配項 $F(\eta)$ ひずみ勾配に基づく非局所作用を表現する。ひ ずみ勾配項 $F(\eta)$ の具体系は, $\bar{k}$ を材料定数, $b$ をバーガース ベクトルとし，次式で与える(1)(2).

$$
F\left(\eta^{(\alpha)}\right)=\operatorname{sgn}\left(\eta^{(\alpha)}\right) \frac{\bar{k}}{p_{\eta}}\left(\frac{l_{\text {defect }}}{b}\left|\eta^{(\alpha)}\right|\right)^{1 / 2}
$$

不適合度を次式に示すように硬化比に導入し, 解析に反映 する.

$$
Q_{\alpha \beta}=\delta_{\alpha \beta}+f_{\alpha k} S_{\beta k}+\delta_{\alpha \beta}\left(F\left(\alpha^{(\alpha)}\right)+F\left(\eta^{(\alpha)}\right)\right)
$$

高密度転位組織である A スケールにおける高転位密度項 $F\left(\eta_{A}^{(\alpha)}\right)$ を次式にて表現する。

$$
F\left(\alpha_{A-l a t h}^{(\alpha)}\right)=k\left(\Delta d_{\text {cell }}^{A-l a t h(\alpha)}\right)^{-1}
$$

ここで $\left(\Delta d_{\text {cell }}^{A-l a t h}\right)$ は有効セルサイズであり，次式で表される.

$$
\left(\Delta d_{\text {cell }}^{A-\operatorname{lath}(\alpha)}\right)^{-1}=\left(\Delta d_{\text {cell }}^{A-\operatorname{lath}(\alpha)}(0)\right)^{-1}+e_{B A}^{-1} k^{-1}+F\left(\eta_{A B}\right) \text { (6) }
$$

また，ラス組織である $\mathrm{B}$ スケールから A スケールへの相互 作用項 $F\left(\eta_{B A}^{(\alpha)}\right)$ を次式で表す.

$$
F\left(\eta_{B A}^{(\alpha)}\right)=\operatorname{sgn}\left(\eta^{(\alpha)}\right) \frac{\bar{k}}{p_{\eta}}\left(\frac{l_{\text {defect }}}{b}\left|\eta_{B A}^{(\alpha)}\right|\right)^{1 / 2}
$$

これらより得られたスケール間の相互作用 $F\left(\alpha_{A-\text { lath }}^{(\alpha)}\right)$, $F\left(\eta_{B A}^{(\alpha)}\right)$ も同様に硬化比 $\mathrm{Q}_{\alpha \beta}$ に与えることでスケール間の相 互作用の表現を試みる.

\section{3. ラスパケット組織のクリープ変形解析}

3-1.解析モデル解析条件

解析モデルを Fig.3に示す. 本解析では 7 結晶モデルとし, 旧オーステナイト粒の中心に先ほどのラスブロック組織を 埋め込み, 基底強度の概念を導入し, クリープ変形解析を行 った.

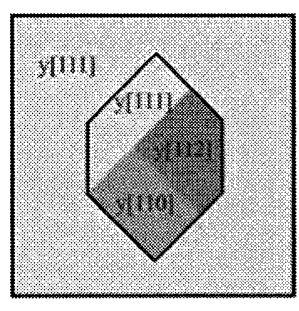

(a)

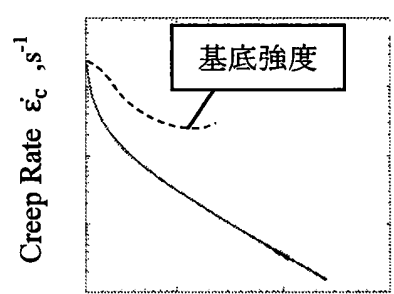

Time Steps

(b)
Fig1. Schematic drawing of analytical model (a) and nominal stress history for creep analysis (b).

\section{3-2.相互作用によるクリープ速度の変化}

本解析では Fig.2 に示す基底強度の概念に基づき，ラス組 織にあらかじめ A, B スケールと相互作用による強化を施し, 回復によりそれぞれの強化機構が失われ，不均質回復による 劣化が生じるというモデルを再現した. そこで新たに導入し た高密度転位組織の強化を担う有効セルサイズ $\left(\Delta d_{\text {cell }}^{A-l a t h}\right)$ と，相互作用項である $F\left(\eta_{A B}\right), F\left(\eta_{B A}\right)$ による影響を検討す る.

得られたクリープ速度を Fig.3 に示す. すべての強化を行 ったものを base とし, $F\left(\eta_{A B}\right), F\left(\eta_{B A}\right),\left(\Delta d_{\text {cell }}^{\text {A-lath }}\right)$ の影響 を小さくしたものをそれぞれ示す. $F\left(\eta_{A B}\right)$ による影響は非 
常に小さいのに比べ, $F\left(\eta_{B A}\right)$ の強化をなくしたものは劣化 が急速に進んでいる. また, $\left(d_{\text {cell }}^{\text {A-lath }}\right)$ の影響を小さくした ものはさらに劣化が早まるという結果が得られた. これらの 結果は本モデルが A,B と相互作用の影響を考慮したもので あるということを示すとともに，A スケールにおける強化部 分がラス組織の強度を担っているということを示唆してい る.このスケール間強化モデルを用い，スケール間のエネル ギの流れを評価する.
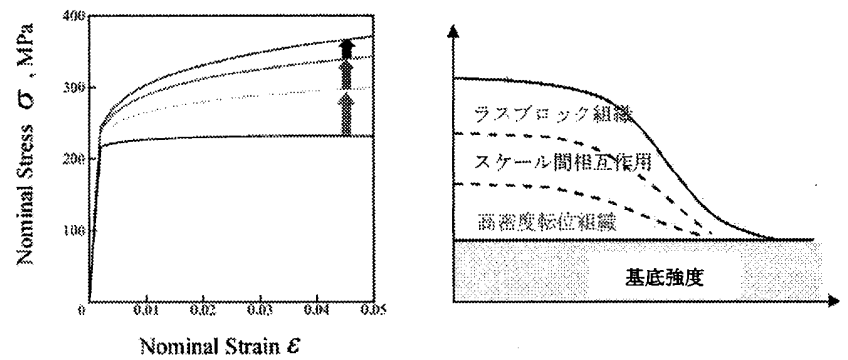

Fig.2 Comparison of $\sigma-\varepsilon$ between based strength and three conditions and schematic drawing of based strengths

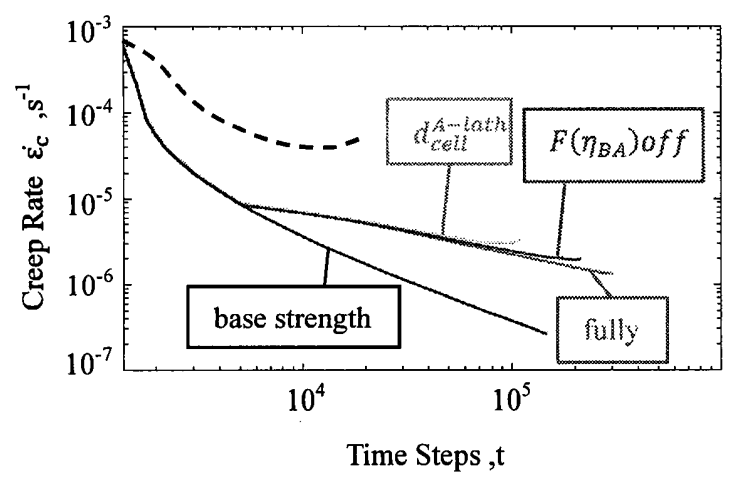

Fig.3 Comparison of $\dot{\varepsilon}_{c}-t$ curves between three recovering conditions together with those with base and fully rasised strengths.

4-3.スケール間のエネルギ輸送

A スケール: 高密度転位組織 B スケール：ラスマルテン サイト組織, この両スケール間の相互作用を考慮した. 次式 で表される Flow-Evolutionary 則を用いてエネルギの流れの 評価を行う.

$$
\eta_{\mathrm{kk}}=\kappa \delta U^{e}
$$

ここで $\kappa$ は輸送係数であり，エネルギのゆらぎと不適合 度の双対線図における傾きを表しており，時間の関数となっ ているFig.5にA，Bスケール，Fig.6にAからBへの相互作用場 における双対線図を示す，両グラフより，Bスケールにおい ては弾性ひずみエネルギのゆらぎは増大し続け，Aスケール では逆に減少し続ける.これはA スケールの高密度転位構造 の崩壊・回復により蓄えられたエネルギが解放され，スケー ル間相互作用場を介し， B スケールへと輸送される. そして 輸送されたエネルギは不均質に蓄積される.この輸送された エネルギにより不均質回復が促進され，よりひずみエネルギ のゆらぎが増大する．その影響が再びA スケールへと流れ， さらに崩壊を促進するという負のフィードバックになって いると考えられる. 不均質回復が生じる前後でのBスケール の不適合度項 $F(\eta)$ の分布をFig.4 に示す. 不均質回復が生じ る前ではほとんど同様の分布を示しているが, 不均質回復後 では, 回復を与えたもののほうがラスの境界がぼやけており， 崩壊が生じていることがわかる.
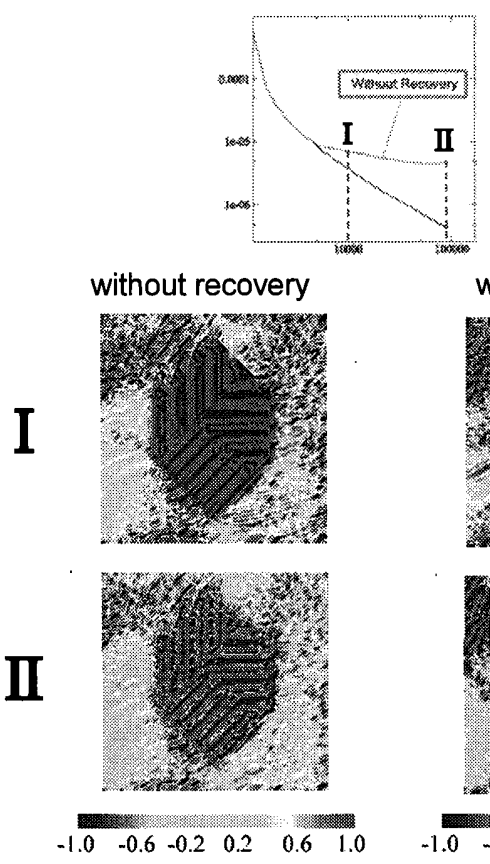

with recovery
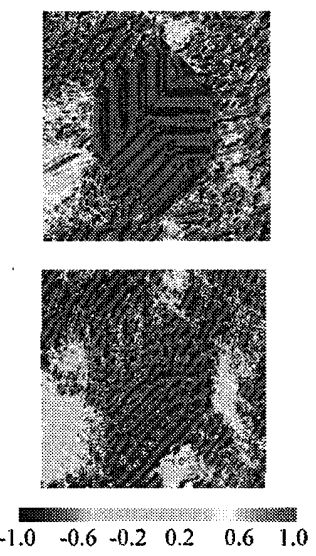

Fig.4 Changes in contour diagrams of $F\left(\eta_{B}\right)$ comparing with and without recovery.

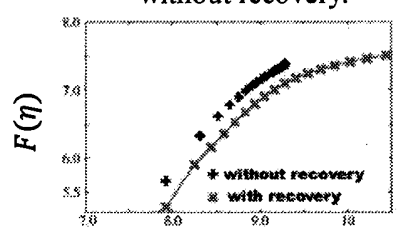

$\delta U^{e}\left(\times 10^{2}\right)$

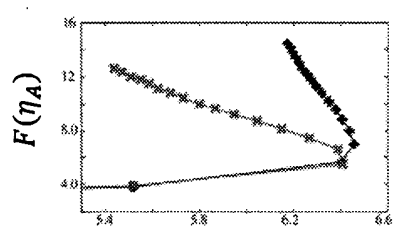

$\delta U_{A}^{e}\left(\times 10^{2}\right)$
Fig.5 $\delta U^{e}$ or $\delta U_{A}^{e}$ VS $F(\eta)$ comparing with and without recovery.
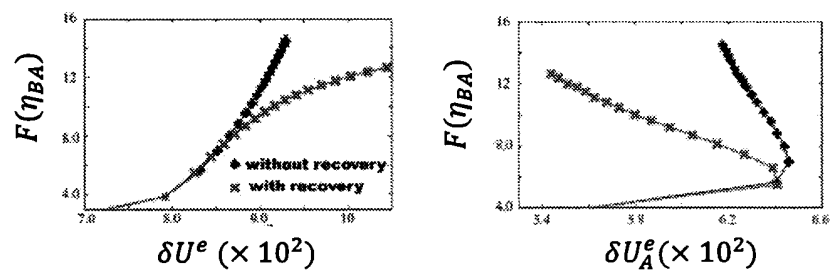

Fig.6 $\delta U^{e}$ or $\delta U_{A}^{e}$ VS $F\left(\eta_{B A}\right)$ comparing with and without recovery.

5.結言

本解析ではラス組織を模擬し，得られた同組織を用いて， ラスパケット組織のクリープ変形解析を行った. スケール間 での相互作用項の導入による影響を, 回復の有無において, Flow-Evolutionary 則により比較・検討した. そこから，スケ ール間でのエネルギのやり取りが行われていることが示唆 された.

本研究遂行にあり神戸大学院 高柳哲平氏（現 : 株式会社 豊田自動織機）の協力を得た．記して謝意を表する。

\section{参考文献}

1) 岸本和也, 不適合度テンソルを用いたラス組織のモデリ ングとクリープ強度に関するシミュレーション, 神戸大 学修士論文, (2011)

2) Aoyagi, Y., Hasebe, T., Key Engineering Materials, 340-341, (2007), 217 